\title{
The Effect of Different Price Presentations on Consumer Impulse Buying Behavior: The Role of Anticipated Regret
}

\author{
Hong Zhou, Zhe Gu \\ Management School, Jinan University, Guangzhou, China \\ Email: doreengu9086@gmail.com
}

Received 2 January 2015; accepted 19 January 2015; published 23 January 2015

Copyright $(02015$ by authors and Scientific Research Publishing Inc.

This work is licensed under the Creative Commons Attribution International License (CC BY). http://creativecommons.org/licenses/by/4.0/

c) (i) Open Access

\begin{abstract}
Previous research has shown that personal qualities and shopping situations affect choice of consumer impulse buying behavior during sales promotion. When implementing a price reduction, retailers tend to favor one practice over the other. Yet how different implementations of a price promotion influence consumer impulse buying behavior has been insufficiently studied. Here, we framed a price reduction in the amount of money versus percentage on products to investigate how the underlying mechanism (anticipated regret) influences likelihood to impulse buying. Compared with percentage-off presentation, the findings indicate that presentation shown at the amount of money leads to higher anticipated regret and consumer impulse buying intention. We also find that the price level of product is the boundary condition, which plays a moderating role.
\end{abstract}

\section{Keywords}

Price Promotion, Anticipated Regret, Impulse Buying, Framing Effect

\section{Introduction}

As a result of their ability to stimulate sales in the short run, the use of price-based promotions has risen steadily. Since price discounts have traditionally been the dominant form of consumer promotion, consumers are aware of and often expect price deals and therefore simply lowering price is often problematic. In developing price promotions, managers not only make decisions related to promotion depth but also decide how to frame the discount, in order to increase consumers' impulse buying. However, when we are faced with different promotional price information, such as “the original price is $¥ 150$, for $¥ 120$ now” or “the original price is $¥ 150$, for $20 \%$ discount now”, which one makes you feel more regretful and have shopping impulse for not buying it? Promo- 
tional price is often generally divided into two different forms: based on the amount of money or based on percentage-off. According to the framing effect, the same information using different means of expression will result in different cognitive effects, and then leads to different attitudes and behaviors. Prior research has demonstrated that our cognitive judgments are indeed influenced by the way our decision information processing is framed [1]. Presenting a price promotion in different ways is similar to the framing of purchase decisions, giving that the benefits received by consumers from the promotion are constant. A number of marketing researchers have considered price promotion as a very important marketing stimulation to motive consumers, and consumers' feeling of anticipated regret is also an incentive to purchase. So we apply prospect theory to analyze the difference between two types of framing price promotion massages from the role of anticipated regret, and investigate the attributes of product price as the boundary condition to influence its effect. As a result of it, how will different price promotion presentations impact on consumers' impulse buying behavior, and how does it work through? Therefore, the purpose of this study is to investigate how the framing presentation of price promotion influences consumers' anticipated regret of promotions and their impulsive purchase.

\section{Literature Review}

\subsection{Alternative Ways to Frame Price Promotions}

During price promotion, the attractiveness to consumer primarily reflects in price, and therefore it is necessary to find out the underlying cause of what contexts the different price promotion presentations will bring better results. However, how different implementations of the same price promotion affect consumers' perceptions of the promotion and their impulsive purchase decisions has been insufficiently studied. In the assessment of a promoted price, framing may affect consumers' estimates of the promotion value (e.g., Krishna et al., 2002) and thus, current choice [2]. Devon DelVecchio et al. (2007) [3] found that promotion frame (percentage-off versus cents-off) moderates the effect of promotion depth on post-promotion price expectations and choice. Shih-fen S Chen et al. (1998) [4] has framed a price reduction in percentage versus dollar terms on either a high-pricing or a low-pricing product. For the high-pricing product, a price reduction framed in dollar terms seemed more significant than the same price reduction framed in percentage terms. Furthermore, whether consumers process price information in an absolute or relative sense affects their perceptions of a price discount (Grewal and Marmorstein, 1994; Heath, Chatterjee, and France, 1995) [5] [6].

Some researchers from the view of information processing to explore the process of consumer perception of price discounts and try to explain the mechanism for consumer to underestimate the price discount. Inaccurate calculation of the price promotions often leads to underestimation of the price discount (Kim and Kramer, 2006) [7]. Meanwhile, a study by Kim and Kramer (2006) [8] found that price discount based on percentage played a positive impact on consumer novelty perceived savings and purchase intention, that is, the more innovative in the form of price discounts, the more savings and purchase intention consumer would feel. Yet there is still lack of research from the prospect of consumers' regret feeling to explore the influence of different price promotion (based on the amount of money vs. based on percentage-off) on consumers' perception of price discount and impulse buying.

\subsection{Anticipated Regret}

Social psychology and behavioral decision theory have given much attention to regret, but regret is only beginning to be fully examined in the marketing literature on purchase decisions (Simonson, 1992) [9] and customer satisfaction and repurchase intentions (Inman, Dyer, and Jia, 1997; Inman and Zeelenberg, 2002; Zeelenberg and Pieters, 1999) [10]-[12]. According to previous research, regret affects people's decision-making process in two ways: on one hand, it makes people correct a wrong decision after purchase (Gilovich \& Medvec, 1995) [13]; on the other hand, before they make a decision, people often expect that if the result turn out to be wrong, they will experience the anticipating feeling of regret so that they change their choice, there are some empirical literature on regret-minimization as a decision strategy (Bell, 1982; Loomes \& Sugden, 1982) [14] [15]. That the former occurs after the purchase decision is called experienced regret; and that the latter occurs before people make a purchase decision is called anticipated regret. Zeelenberg et al. (1996) [16] confirmed the anticipated regret would lead to a safer option because of risk aversion. However Larick and Bole (1995) [17] shown that anticipated regret could make people tend to more risk seeking, rather than escaping risk. For these two contrary 
views, the following studies find a significant phenomenon, that is, consumers whether it is "risk-averse" or "risk-seeking" in the decision-making process will tend to make a choice minimizing the degree of regret, namely whether it is planned to purchase or impulse buying, people often prefer to minimizing regret when making decisions, instead of risk minimization decisions. In addition, Tykocinski (2001) [18] summarized the essence of promotion (time limitation and material incentives), and proposes promotion would lead to "inaction regret" (miss the promotion chance or perceive opportunity cost).

\subsection{Factors Which Influence Impulse Buying}

Generally speaking, decisions made by consumer are always under deliberation and comparison. Yet in some special situations, consumers may choose products without forethought or planned, when driven by promotion stimulation, it is easy to increase their impulse buying intention. The term "impulse buying” is generally considered to be synonymous with "unplanned buying”- that is, it describes any purchase which a shopper makes but has not planned in advance. Stern (1962) [19] carried out nine factors that are major influences in impulse buying: low price, marginal need for item, mass distribution, self-service, mass advertising, prominent store display, short product life, small size or light weight, ease of storage. Beatty \& Ferrell (1998) [20] divided factors into two sides: endogenous way and exogenous way. The exogenous variable refers to individual differences (such as the extent of shopping crazy and impulsive consumption tendency) and the shopping context (such as time and money), and the endogenous variable refers to the positive or negative emotions, browsing behavior. Dholakia (2000) [21] established a model of the formation and consolidation about impulse buying behavior. He reclassified the influencing factors carried out by previous papers, and proposed influencing factors of these three areas: marketing stimuli (including product display and promotional activities), situational factors (including the consumer's financial situation and mood then) and impulsive traits. This classification has been widely recognized by further research, this study will base on his classification for research.

\section{Research Hypotheses}

Based on previous research, product characteristics including product category, price, and the related symbolism of product is the reason that affects consumer impulse buying. Therefore, some products will attract more consumers because of such influencing factors. Price has always been considered as an important factor in impulse buying (Zhou \& Wong, 2003) [22]. Specifically, when they face the price discounts, consumers are more prone to impulse buying behavior. Prior literature shows that different forms of price presentation will also have different effects on consumers' purchase intention. The form based on the amount of money is more intuitive than the form based on percentage-off, so that it is easier for consumers to develop a lower price discount perception in their minds, so as to stimulate their impulse buying desire. Accordingly, our study concluded, for customers, the form based on the amount of money is likely to perceive much more stimuli promotional value than the form based on percentage-off, as a result of it, they will have a stronger impulse buying tendency. With this reasoning in mind, we state our first hypothesis:

H1: When consumers face a price discount, promotions presented at the amount of money is more likely to increase their impulse buying behavior than presented in percentage-off terms.

An important element of regret theory is that people usually tend to regret averse. Therefore, in the consumer purchase decision-making process, either before or after the purchase, they will take the initiative to seek for regret minimization choice [23] [24]. Seeking to minimize the regret of purchase can cause two different options: risk-seeking choices (impulse buying) or risk aversion choice (planned purchase).

When consumers face promotional incentive especially price discounts, they will be afraid of giving up then this product has returned the original price, or finding the price at other malls are all higher than this mall, and they have missed the promotion in this mall, that is to say, they missed out on the best time to buy the product, then this counterfactual thinking will give consumers some emotional regret, at this time if consumers take actions to minimize the regret, they are likely to implement impulse buying behavior. Meanwhile, compared with the price discount based on the percentage-off, the form based on the amount of money makes consumer perceive more missed opportunity cost, so that it leads to stimulate more anticipated regret. Formally, we propose the following:

H2: When consumers face a price discount, promotions presented at the amount of money is more likely to increase their anticipated regret than presented in percentage-off terms. 
Studies have shown that anticipated regret have a direct impact on consumer impulse buying, which is moderated by impulse characteristics and shopping situation (Chengyue Yin, 2009) [25]. The personal traits and psychological perception of consumers will have an impact on anticipated regret, too [26]. Paying a lower price for a product of given quality can discourage deliberation, in a sense "dumbing down" the purchase encounter by making it less consequential. Specifically, they argue that price promotion lowers a consumer's motivation to exert mental effort, in which case purchase decisions are guided less by extensive information processing and more by a quicker, easier, strong conditioner of preference: affect [27]. Thus, we proposed the following hypothesis:

H3a: Consumers' feeling of anticipated regret has a positive impact on their impulse buying intention.

H3b: Consumers' feeling of anticipated regret is a mediating variable between the form of price presentations and consumer impulse buying intention.

Absolute or relative price discounts will bring to a different perception of the consumer price discounts, and the price level is the reason for this phenomenon (Shih-Fen S. Chen et al., 1998) [28]. At the same time, because of the difficulty in calculating the amount of the discount is larger on the form based on the percentage than the form based on the amount of money, so it is easily for consumers to underestimate the amount of the discount, thereby weakening the consumers "regret not buying it" mentality. There is an implicit premise that consumers will finally bring the price discount savings amount into the amount of money rather than percentage. That being the case, it is inevitable that underestimating percentage-off term is positively related to the relative price. The higher of the relative price, the greater underestimation of the discount based on the percentage-off, and the less effect of anticipated regret on consumer will work. For example, a ¥ 1000 discount on a $¥ 20,000$ automobile appears significant in terms of dollar savings, but the equivalent 5\% discount seems less attractive. Accordingly, we conclude that price presentations make an effect on anticipated regret, which is affected by products relative price level, because it is difficult to absolutely define high-pricing or low-pricing, so we intend to investigate it from the role of relative price. For relatively high-pricing products, discount presented in percentage-off rises less anticipated regret than discount presented at the amount of money; and for relatively low-pricing products, the impact on anticipated regret by different price discount presentations will be reduced or even become insignificant. Therefore, we come up with the following research hypothesis:

H4: The impact on anticipated regret by different price presentations (based on the amount of money vs. based on the percentage) is moderated by product relative price level.

\section{Study Design}

In our study, we use $2 \times 2$ two-factor experimental design, firstly we test the best stimulate product in pilot study; secondly we organize a study to test $\mathrm{H} 1$ to H4 by Scenario questionnaire.

\subsection{Pilot Study}

Dittmar et al. (1995) [29] has proposed 13 kinds of commodity, which are easy to cause consumers' impulse buying purchase. Combined with the actual situation of Chinese market and consumer purchasing ability, we deleted some category, and sorted out the following seven kinds of products: jewelry, clothing, sporting goods, magazines, health products, audio and video supplies and computer software. Then we randomly selected fifty people from freshman, including 25 boys and 25 girls. The questionnaire is mainly on seven kinds of product description, we ask them to answer this question, "I would buy this product impulsively" to test their views. Questionnaires were measured by Likert scale from strongly disagree (1) to strongly agree (7). It was found that above all of the category, casual clothing has the highest average scores in causing impulse buying behavior (M $=6.01, \mathrm{p}<0.01$ ), therefore we determined to use it as our study stimulate object.

\subsection{Participants}

A total of 340 undergraduate students from Jinan University participated in the experiment. They were randomly assigned to a scenario condition. In this experiment, we get back 319 available questionnaires based on the amount of money/based on the percentage-off, and the effective rate is $93.82 \%$. The number of men and women in the sample are substantially equal. Specific experimental design is shown in Table 1.

\subsection{Procedure}

In this study, we empirically examined our research hypotheses in two different price presentation settings by 
Table 1. Experimental design.

\begin{tabular}{ccc}
\hline & Price presented at the amount of money & Price presented on percentage \\
\hline High-pricing & $85(80)$ & $85(82)$ \\
Low-pricing & $85(78)$ & $85(79)$ \\
\hline
\end{tabular}

Note: figures in brackets are the actual number of available questionnaires collected.

fully crossing high-pricing product and low-pricing product. In a $2 \times 2$ between-subjects experiment design, we manipulated price presentation (based on the amount of money vs. based on the percentage-off) and price level (high-pricing vs. low-pricing). Upon arrival, participates read the brief description about a specific shopping situation (high-pricing or low-pricing), then answer the questionnaire according to what they feel after reading the given scenario.

\subsection{Measurement}

Following the pattern set by Zeelenberg et al. (1996) [16], respondents circled their choice ("buy the jacket in the promotion now" or "not buy the jacket in the promotion now") and then indicated the strength of their preference for the chosen option on a 7-point scale ranging from 1-weak preference to 7-strong preference. Finally, respondents were asked to write down how they thought they would feel after making this choice. As for the measurement of anticipated regret, we apply the research items form Michael Tsiros et al. (2010) [30] by asking "If I do not buy the product now, I will regret it later" and the same to choose option on a 7-point scale ranging from 1-weak preference to 7-strong preference.

\section{Results}

\subsection{Reliability and Validity}

By using SPSS19.0 to analyze the reliability and validity of the questionnaire, the result shows that our scale Cronbach's alpha coefficient is 0.830 , significantly higher than the minimum standard of 0.7 , indicating that the current questionnaire has good internal consistency. Next, we use AMOS 4.0 software for confirmatory factor analysis (CFA), the fit indexes are: $\mathrm{CMIN} / \mathrm{DF}=2.3$, GFI $=0.925, \mathrm{CFI}=0.943$, RMSEA $=0.041$, showing that the model has the advantage of high goodness of fit. Meanwhile, the AVE for "impulse buying intention" and "anticipated regret" are 0.62 and 0.51 , reached a critical value of 0.5 , indicating convergent validity was acceptable.

\subsection{Hypothesis Tests}

\subsubsection{Effect of Price Presentation on Consumer Anticipated Regret and Impulse Buying Intention}

We chose the two groups of high-pricing product for our experimental research, in order to compare how different price presentations (based on the amount of money vs. based on percentage-off) make a difference on the impact of anticipated regret and impulse buying intention. We apply anticipated regret and impulse purchase intention as dependent variables, and we apply price presentation as independent variable. The analysis of ANOVA showed that the two variables are significantly affected by the presentation of price discounts; see Table 2, and Table 3.

The results suggest that participants gave higher impulse buying intention when they were faced the presentation based on the amount of money $(M=5.98)$ than the presentation based on the percentage-off $(M=4.88 ; \mathrm{p}<$ 0.001), in support of H1. Furthermore, participants experienced higher anticipated regret when they were faced the presentation based on the amount of money $(\mathrm{M}=4.67)$ than the presentation based on the percentage-off ( $\mathrm{M}$ $=3.68 ; \mathrm{p}<0.001$ ), in support of $\mathrm{H} 2$.

\subsubsection{The Mediating Role of Anticipated Regret}

We conducted three regression analyses (for full results, see Table 4 and Table 5). Model 1 in Table 5 indicated that price presentation had a significant positive impact on consumer impulse buying intention. And model 2 showed that, on the basis of a model 1, after we add anticipated regret into the regression model, the model sig- 
Table 2. The impact of price presentation on impulse buying intention.

\begin{tabular}{cccccc}
\hline Source & Type III SS & DF & Mean Square & F Value & $\mathrm{p}<$ \\
Price Presentation & 12.334 & 1 & 12.334 & 7.889 & 0.01 \\
Error & 110.231 & 66 & 1.457 & & \\
\hline
\end{tabular}

Table 3. The impact of price presentation on anticipated regret.

\begin{tabular}{cccccc}
\hline Source & Type III SS & DF & Mean Square & F Value & $\mathrm{p}<$ \\
\hline Price Presentation & 20.173 & 1 & 20.173 & 8.921 & 0.001 \\
Error & 99.867 & 66 & 1.698 & & \\
\hline
\end{tabular}

Table 4. Regression test between anticipated regret and price presentation.

\begin{tabular}{|c|c|c|c|c|c|c|}
\hline \multirow{2}{*}{ Model } & & \multicolumn{2}{|c|}{ Unstandardized Coefficients } & \multirow{2}{*}{$\begin{array}{c}\text { Standardized Coefficients } \\
\text { Beta }\end{array}$} & \multirow{2}{*}{$\mathrm{t}$} & \multirow{2}{*}{ Sig. } \\
\hline & & $\mathrm{B}$ & Std. Error & & & \\
\hline \multirow{2}{*}{1} & (Constant) & 3.875 & 0.232 & \multirow{2}{*}{0.433} & 16.901 & 0.000 \\
\hline & Price Presentation & 1.021 & 0.301 & & 3.011 & 0.000 \\
\hline
\end{tabular}

Note: $\mathrm{R}^{2}=0.15, \mathrm{~F}_{1.66}=14.80, \mathrm{p}<0.001$.

Table 5. Regression test among impulse buying intention, price presentation and anticipated regret.

\begin{tabular}{|c|c|c|c|c|c|c|}
\hline & \multirow{2}{*}{ Model } & \multicolumn{2}{|c|}{ Unstandardized Coefficients } & \multirow{2}{*}{$\begin{array}{c}\text { Standardized Coefficients } \\
\text { Beta }\end{array}$} & \multirow{2}{*}{$\mathrm{t}$} & \multirow{2}{*}{ Sig. } \\
\hline & & B & Std. Error & & & \\
\hline \multirow{2}{*}{1} & (Constant) & 4.581 & 0.193 & & 20.773 & 0.000 \\
\hline & Price Presentation & 0.798 & 0.256 & 0.319 & 2.654 & 0.013 \\
\hline \multirow{3}{*}{2} & (Constant) & 2.731 & 0.391 & & 4.901 & 0.000 \\
\hline & Price Presentation & 0.023 & 0.212 & 0.013 & 0.183 & 0.882 \\
\hline & Anticipated Regret & 0.496 & 0.129 & 0.465 & 3.870 & 0.006 \\
\hline
\end{tabular}

Note: 1) model 1: $\left.\mathrm{R}^{2}=0.10, \mathrm{~F}_{1.66}=7.906, \mathrm{p}<0.05 ; 2\right)$ model $2: \Delta \mathrm{R}^{2}=0.42, \mathrm{~F}_{2.64}=26.89, \mathrm{p}<0.01$.

nificantly improved the goodness of fit $\left(\Delta \mathrm{R}^{2}=0.42, \mathrm{~F}=26.89, \mathrm{p}<0.01\right)$, the positive impact of anticipated regret on impulse buying was proved. Meanwhile, as we expect, the impact of price presentation on consumer impulse buying intention was no longer significant. Therefore we could find that: 1) anticipated regret has a positive effect on customer impulse buying intention, H3a is supported; 2) consistent with H3b, anticipated regret mediates the effect of price presentation on consumer impulse buying intention.

\subsubsection{Moderating Role of Price Level}

On one hand, as for impulse buying intention, the presentation based on the amount of money $(\mathrm{M}=5.91)$ was significantly higher than the presentation based on the percentage $(M=5.10)$ in high-pricing group $(F=6.78, p$ $<0.005)$; however, in low-pricing group, there was no significant difference, the presentation based on the amount of money $(\mathrm{M}=5.22)$ was nearly the same as the presentation based on the percentage $(\mathrm{M}=5.31 ; \mathrm{F}=$ $0.65, \mathrm{p}>0.10$ ), see Figure 1; on the other hand, for anticipated regret, the presentation based on the amount of money $(M=5.09)$ was significantly higher than the presentation based on the percentage $(M=4.34)$ in highpricing group $(\mathrm{F}=13.22, \mathrm{p}<0.01)$; however, in low-pricing group, there was no significant difference, the presentation based on the amount of money $(\mathrm{M}=4.56)$ was nearly the same as the presentation based on the percentage ( $\mathrm{M}=4.77 ; \mathrm{F}=0.92, \mathrm{p}>0.10)$, see Figure 2 . These findings provide support for $\mathrm{H} 4$. 


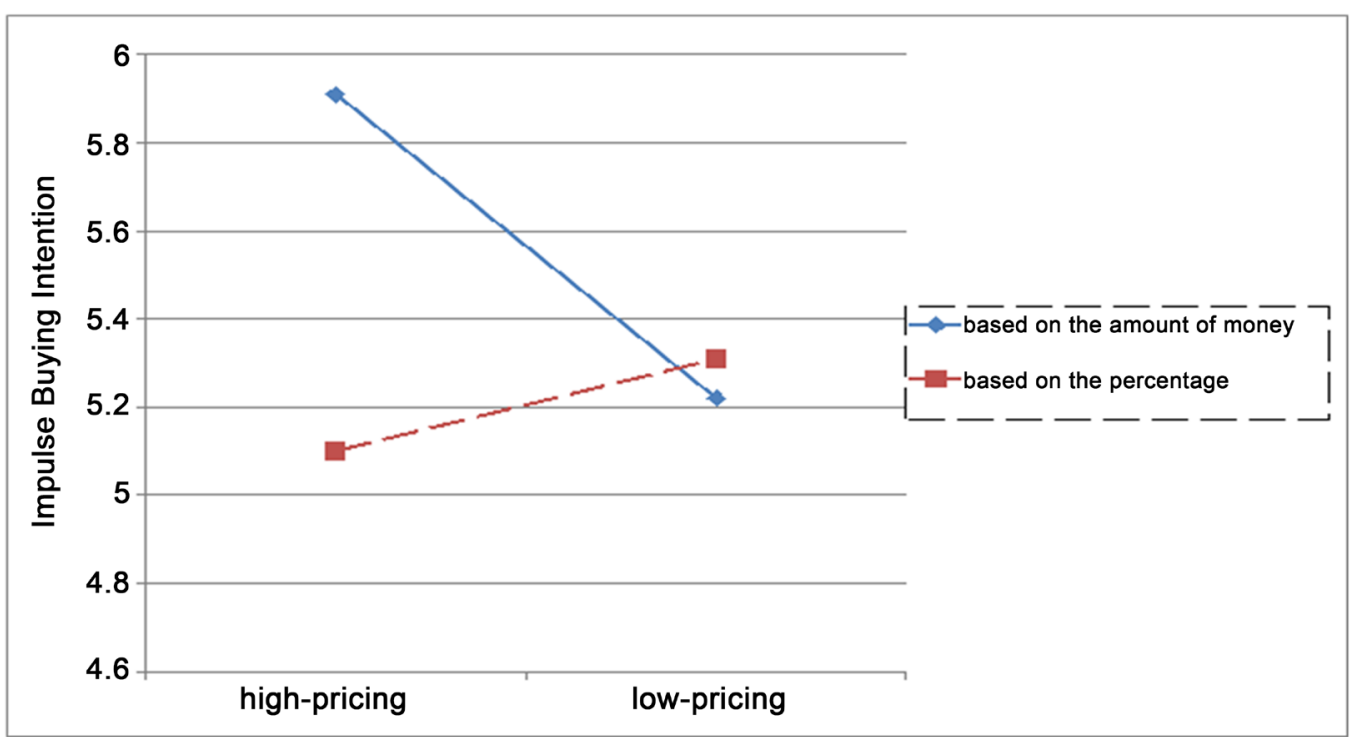

Figure 1. Effect of price presentation on consumer impulse buying intention.

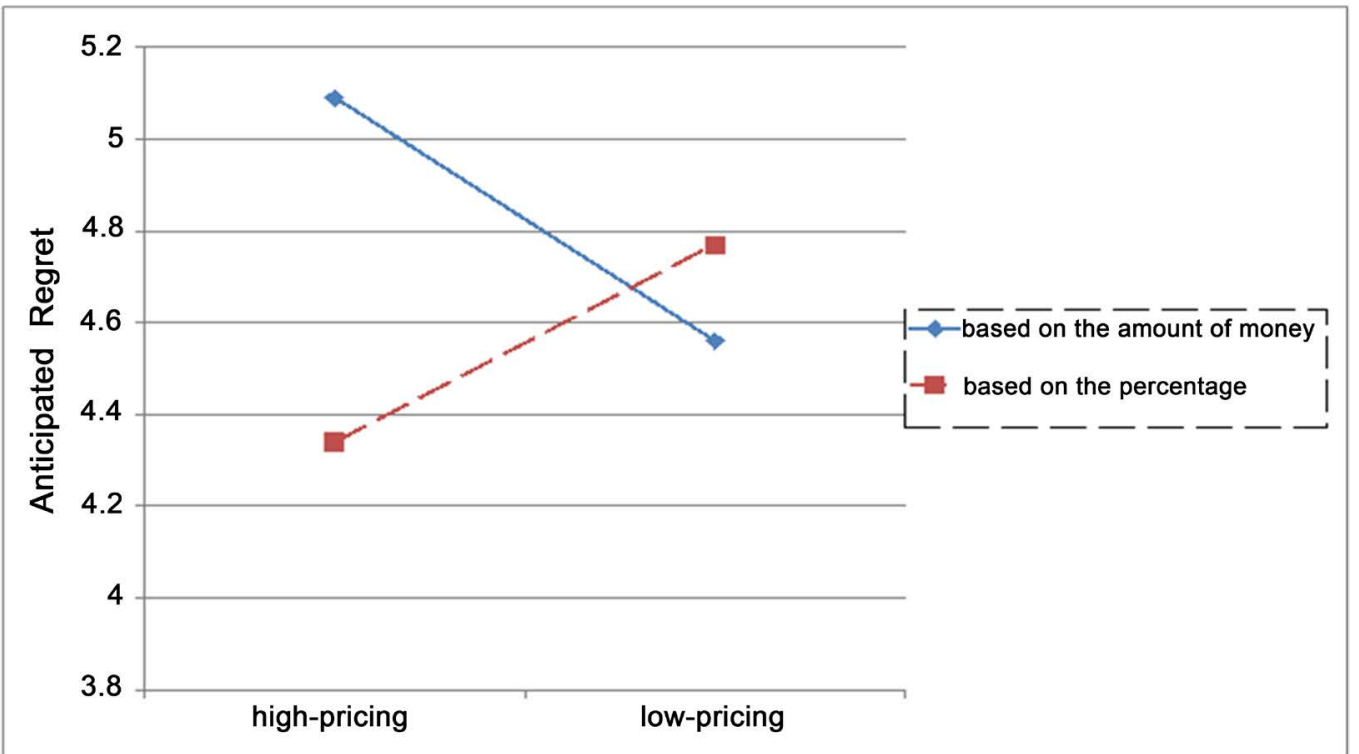

Figure 2. Effect of price presentation on consumer anticipated regret.

\section{Discussions}

\subsection{Theoretical Contribution}

Our study investigates the mechanism about the impact of different price promotion incentives on consumer impulse buying behavior from the perspective of anticipated regret. Although the term "impulse buying" is one of the oldest and most well-established constructs in the promotion marketing literature, we are the first to combine it with different promotional incentives and consumers' feeling of anticipated regret. What's more, we try to find out the boundary conditions of the effect that different promotional price presentations will lead to varying degree of consumers' anticipated regret and impulse buying behavior.

\subsection{Marketing Implication}

This study makes up for the lack of previous studies; we firstly explore the internal mechanism of the consumer 
impulse buying behavior from the view of price presentation, combined with anticipated regret theory. The results will help marketing managers better understand consumer impulse buying decision-making process, especially from the perspective of regret and price promotion stimulus to motivate consumers' impulse buying behavior. The emotion of anticipated regret has an impact on decision-making processing. If people expect to regret it in the future before making decisions, they will be more cautious in the decision-making process to avoid the occurrence of such experienced regret. It seems that anticipated regret can optimized their purchase decisions. So managers can consciously evoke consumer's anticipated regret with advertisement and other promotional tools to enable consumers highly involved to strengthen the positive impact of anticipated regret, thereby reducing consumers' wrong decisions and achieving greater consumer satisfaction. Also, managers can carry out better marketing design aiming at product characteristics and consumer psychology, in order to achieve better sales targets. Faced with expensive products, marketing strategies should be adjusted, using a more intuitive way as much as possible, such as showing the amount of the discount, which can make consumers take positive action for impulse buying.

\section{Conclusions}

Our research eventually reached the following conclusions:

Firstly, the form of price presentation (based on the amount of money or percentage-off) has a significant impact on consumer impulse buying behavior. The study found that price discounts based on the amount of money could arouse more willingness to buy.

Secondly, anticipated regret is the mediating variable that affects the impact of different price promotion presentations on consumer impulse buying behavior. Once consumers received promotional massage, they might be afraid to miss the chance of buying cheaper products, and then they would experience anticipated regret, and finally it enhances their purchase intention.

Thirdly, our study revealed an important boundary condition of our findings: price level. The results of this study suggest that when the product is in a high price level, the price promotion form based on the amount of money plays a significant role; when the product is in a low price level, two discount forms present no significant difference.

\section{Limitations}

We recognize several limitations that must be taken into account when generalizing our results. The first limitation is that our participants are mainly college students from Guangzhou in order to facilitate the experiment; thus, the results would be disturbed by the limitation in age and local characteristics. Another limitation involves the scales, the scales we used are from foreign countries, although adjustments have been made in accordance with national conditions, but compared with western consumers, Chinese consumers are not the same in many ways, so there still have an impact on the accuracy of measurement to some extent.

Although our experimental design enabled us to isolate the effects of price promotion presentation on consumer impulse buying, it remains unclear if findings would be similar for other promotion incentives; it is our hope that future studies explore this topic. We also call for additional research that investigates how different marketing stimulus interact with other factors prevalent in consumer impulse buying. In addition, future studies might uncover this relationship to actual customer spending to fully realize the financial power of this promotion strategy.

\section{Acknowledgements}

This study was supported by the Social Science Foundation of Guangdong Province, China (GD12CGL15), and the Humanity and Social Science Foundation of Ministry of Education of China (14YJA630099).

\section{References}

[1] Kahneman, D. and Tversky, A. (1979) Prospect Theory: An Analysis of Decision under Risk. Econometrica, 47, 263291. http://dx.doi.org/10.2307/1914185

[2] Krishna, R.B., Lehman, D.R. and Yuan, H. (2002) A Meta-Analysis of the Impact of Price Presentation on Perceived Savings. Journal of Retailing, 78, 101-118. http://dx.doi.org/10.1016/S0022-4359(02)00072-6 
[3] DelVecchio, D., Krishnan, H.S. and Smith, D.C. (2007) Cents or Percent? The Effects of Promotion Framing on Price Expectations and Choice. Journal of Marketing, 71, 158-170. http://dx.doi.org/10.1509/jmkg.71.3.158

[4] Chen, S.-F.S., Monroe, K.B. and Lou, Y.-C. (1998) The Effects of Framing Price Promotion Messages on Consumers' Perceptions and Purchase Intentions. Journal of Retailing, 74, 353-372. http://dx.doi.org/10.1016/S0022-4359(99)80100-6

[5] Grewal, D. and Marmorstein, H. (1994) Market Price Variation, Perceived Price Variation and Consumers' Price Search Decisions for Durable Goods. Journal of Consumer Research, 21, 452-460. http://dx.doi.org/10.1086/209410

[6] Heath, T.B., Chatterjee, S. and France, K.R. (1995) Mental Accounting and Change in Price: The Frame Dependence of Preference Dependence. Journal of Consumer Research, 22, 90-97. http://dx.doi.org/10.1086/209437

[7] Kim, H.M. and Kramer, T. (2006) The Moderating Effects of Need for Cognition Effort on Responses to Multi-Dimensional Prices. Marketing Letters, 17, 193-203. http://dx.doi.org/10.1007/s11002-006-5928-2

[8] Kim, H.M. and Kramer, T. (2006) "Pay 80\%” versus “Get 20\% off”: The Effect of Novel Discount Presentation on Consumers’ Deal Perceptions. Marketing Letters, 17, 311-321. http://dx.doi.org/10.1007/s11002-006-9309-7

[9] Simonson, I. (1992) The Influence of Anticipating Regret and Responsibility on Purchase Decision. Journal of Consumer Research, 19, 105-118. http://dx.doi.org/10.1086/209290

[10] Inman, J.J., Dyer, J.S. and Jia, J. (1997) A Generalized Utility Model of Disappointment and Regret Effects on Post-Choice Valuation. Marketing Science, 16, 97-111. http://dx.doi.org/10.1287/mksc.16.2.97

[11] Inman, J.J. and Zeelenberg, M. (2002) Regret in Repeat Purchase versus Switching Decisions: The Attenuating Role of Decision Justifiability. Journal of Consumer Research, 29, 116-128. http://dx.doi.org/10.1086/339925

[12] Zeelenberg, M. and Pieters, R. (1999) Comparing Service Delivery to What Might Have Been: Behavioral Responses to Regret and Disappointment. Journal of Service Research, 2, 86-97. http://dx.doi.org/10.1177/109467059921007

[13] Medvec, V.H., Madey, S.F. and Gilovich, T. (1995) When Less Is More: Counterfactual Thinking and Satisfaction among Olympic Medalists. Journal of Personality \& Social Psychology, 69, 603-610. http://dx.doi.org/10.1037/0022-3514.69.4.603

[14] Bell, D.E. (1982) Regret in Decision Making under Uncertainty. Operations Research, 30, 961-981. http://dx.doi.org/10.1287/opre.30.5.961

[15] Loomes, G. and Sugden, R. (1982) Regret Theory: An Alternative Theory of Rational Choice under Uncertainty. Economic Journal, 92, 805-824. http://dx.doi.org/10.2307/2232669

[16] Zeelenberg, M., Beattie, J., van der Plight, J. and de Vries, N.K. (1996) Consequences of Regret Aversion: Effect of Expected Feedback on Risky Decision Making. Organizational Behavior and Human Decision Processes, 65, 148158. http://dx.doi.org/10.1006/obhd.1996.0013

[17] Larick, R.P. and Boles, T.L. (1995) Avoiding Regret in Decisions with Feedback: A Negotiation Example. Organizational Behavior and Human Decision Processes, 63, 87-97. http://dx.doi.org/10.1006/obhd.1995.1064

[18] Tykocinski, O. and Pittman, T. (2001) Product Aversion Following a Missed Opportunity: Price Contrast or Avoidance of Anticipated Regret. Basic and Applied Social Psychology, 23, 149-156. http://dx.doi.org/10.1207/S15324834BASP2303_1

[19] Stern, H. (1962) The Significance of Impulse Buying Today. Journal of Marketing, 26, 59-62. http://dx.doi.org/10.2307/1248439

[20] Beatty, S.E. and Ferrell, M.E. (1998) Impulse Buying: Modeling Its Precursors. Journal of Retailing, 74, $169-191$. http://dx.doi.org/10.1016/S0022-4359(99)80092-X

[21] Dholakia, U.M. (2000) Temptation and Resistance: An Integrated Model of Consumption Impulse Formation and Enactment. Psychology \& Marketing, 17, 955-982. http://dx.doi.org/10.1002/1520-6793(200011)17:11<955::AID-MAR3>3.0.CO;2-J

[22] Zhou, L. and Wong, A. (2004) Consumer Impulse Buying and In-Store Stimuli in Chinese Supermarkets. Journal of International Consumer Marketing, 16, 37-53. http://dx.doi.org/10.1300/J046v16n02_03

[23] Tsiros, M. and Mittal, V. (2000) Regret: A Model of Its Antecedents and Consequences in Consumer Decision Making. Journal of Consumer Research, 26, 401-417. http://dx.doi.org/10.1086/209571

[24] Cooke, A.D.J., Meyvis, T. and Schwartz, A. (2001) Avoiding Future Regret in Purchase-Timing Decision. Journal of Consumer Research, 27, 447-459. http://dx.doi.org/10.1086/319620

[25] Yin, C.Y. and Yu, H.Y. (2009) The Impact of Anticipated Regret on Consumer Impulse Buying Behavior. Management Review, 21, 71-93.

[26] McConnell, A.R., Niedermeier, K.E., Leibold, J.M., El-Alayli, A.G., Chin, P.P. and Kuiper, N.M. (2000) What If I 
Find It Cheaper Someplace Else? Role of Prefactual Thinking and Anticipated Regret in Consumer Behavior. Psychology \& Marketing, 17, 281-298. http://dx.doi.org/10.1002/(SICI)1520-6793(200004)17:4<281::AID-MAR2>3.0.CO;2-5

[27] Aydinli, A., Bertini, M. and Lambrecht, A. (2014) Price Promotion for Emotional Impact. Journal of Marketing, 78, 80-96. http://dx.doi.org/10.1509/jm.12.0338

[28] Chen, S.F.S., Monroe, K.B. and Lou, Y.C. (1998) The Effects of Framing Price Promotion Messages on Consumers' Perceptions and Purchase Intentions. Journal of Retailing, 74, 353-372. http://dx.doi.org/10.1016/S0022-4359(99)80100-6

[29] Dittmar, H., Beattie, J. and Friese, S. (1995) Gender Identity and Material Symbols: Objects and Decision Considerations in Impulse Purchases. Journal of Economic Psychology, 16, 491-511. http://dx.doi.org/10.1016/0167-4870(95)00023-H

[30] Tsiros, M. and Hardesty, D.M. (2010) Ending a Price Promotion: Retracting It in One Step or Phasing It out Gradually. Journal of Marketing, 74, 49-64. http://dx.doi.org/10.1509/jmkg.74.1.49

\section{Appendix (Translated from the Original Chinese Text)}

\section{Study Scenario Example:}

Situation 1:

When you hang out at a shopping mall, you find a casual jacket of a famous brand is on sale. It fits your expectations in quality, style and so on, and the sales promotion is really attractive, you have tried it and it fits you very much. This jacket is displayed on the price tag: the original price is $¥ 480$, which is enjoying $40 \%$ discount now (which is $¥ 288$ now).

Situation 2:

When you hang out at a shopping mall, you find a casual jacket of a famous brand is on sale. It fits your expectations in quality, style and so on, and the sales promotion is really attractive, you have tried it and it fits you very much. This jacket is displayed on the price tag: the original price is $¥ 180$, which is enjoying $40 \%$ discount now (which is $¥ 108$ now).

\section{Composition of the Scales:}

\begin{tabular}{|c|c|c|c|c|c|c|c|}
\hline \multirow{2}{*}{$\begin{array}{l}\text { Questionnaire Items } \\
\text { 1. If I don't buy the product now, I will regret it later. }\end{array}$} & \multicolumn{4}{|c|}{ Strongly Disagree } & \multicolumn{3}{|c|}{ Strongly Agree } \\
\hline & 1 & 2 & 3 & 4 & 5 & 6 & 7 \\
\hline $\begin{array}{l}\text { 2. If I don't buy the product now, and I find it reruns to the original price, I will } \\
\text { regret it later. }\end{array}$ & 1 & 2 & 3 & 4 & 5 & 6 & 7 \\
\hline $\begin{array}{l}\text { 3. If I don't buy the product now, and I find it is the cheapest among all the } \\
\text { shopping malls, I will regret it later. }\end{array}$ & 1 & 2 & 3 & 4 & 5 & 6 & 7 \\
\hline $\begin{array}{l}\text { 4. If I don't buy the product now, and I find it is limited supply and sold out, I } \\
\text { will regret it later. }\end{array}$ & 1 & 2 & 3 & 4 & 5 & 6 & 7 \\
\hline 5. I buy things according to how I feel at the moment. & 1 & 2 & 3 & 4 & 5 & 6 & 7 \\
\hline 6. I will impulsively buy this product now. & 1 & 2 & 3 & 4 & 5 & 6 & 7 \\
\hline
\end{tabular}


Scientific Research Publishing (SCIRP) is one of the largest Open Access journal publishers. It is currently publishing more than 200 open access, online, peer-reviewed journals covering a wide range of academic disciplines. SCIRP serves the worldwide academic communities and contributes to the progress and application of science with its publication.

Other selected journals from SCIRP are listed as below. Submit your manuscript to us via either submit@scirp.org or Online Submission Portal.
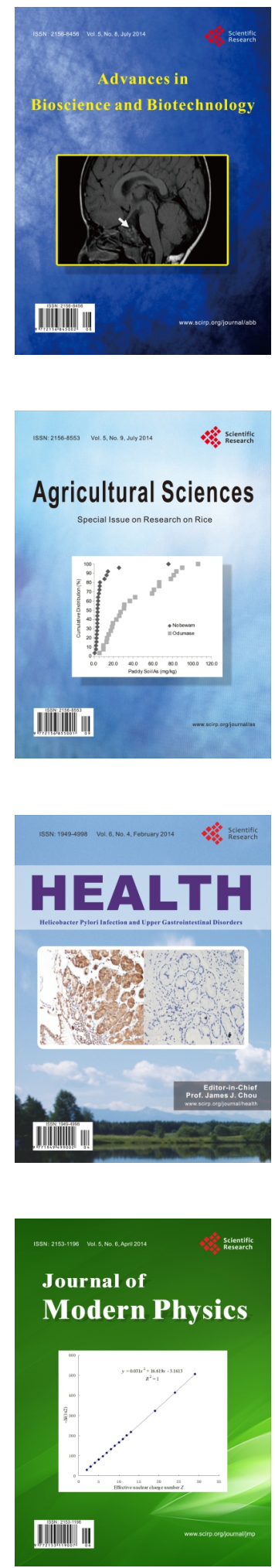
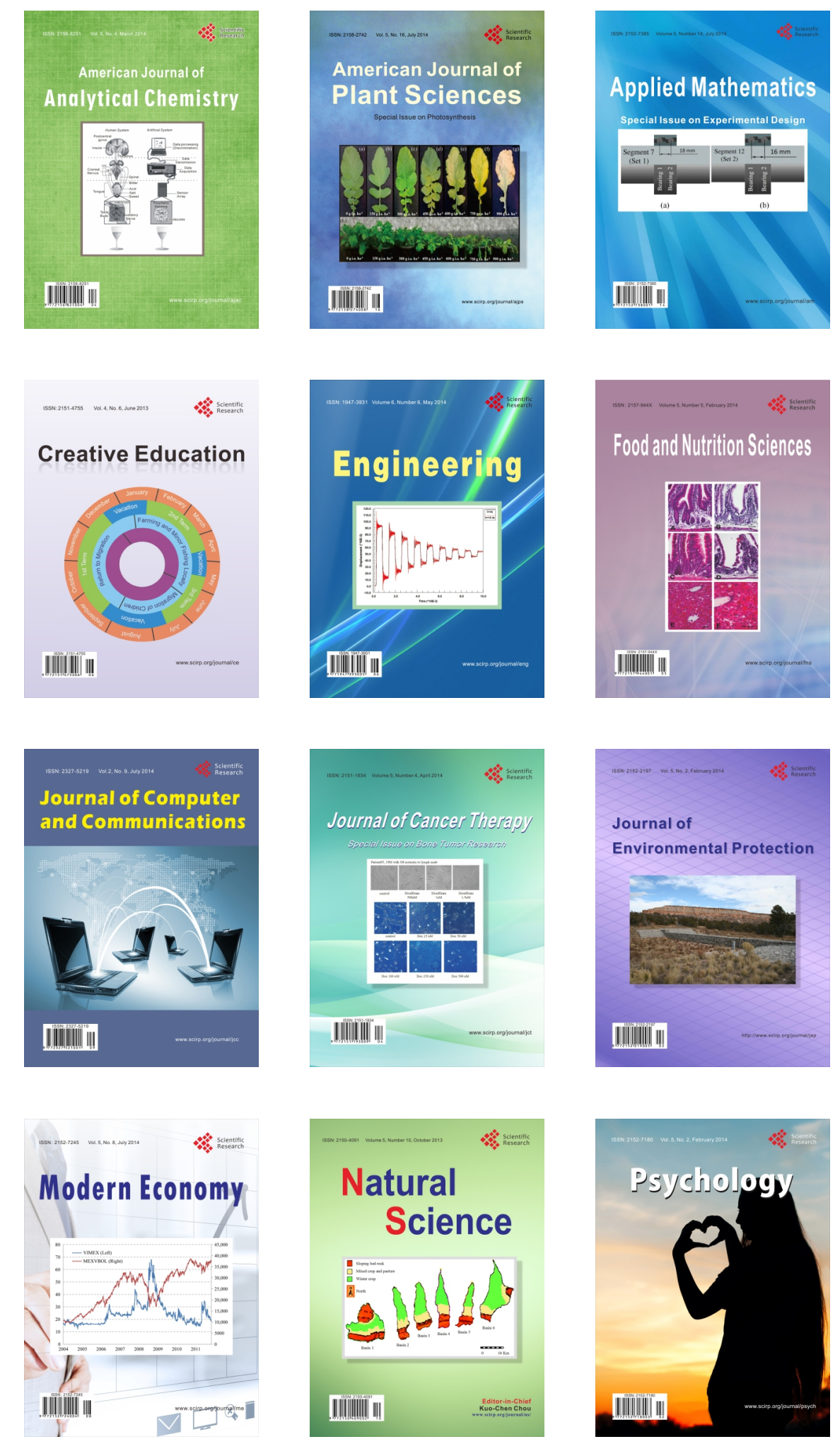